\title{
Displacement, disempowerment and corruption: challenges at the interface of fisheries, management and conservation in the Bijagós Archipelago, Guinea-Bissau
}

Helen CROSS

\begin{abstract}
Small-scale fishers working in the West African Bijagós Archipelago are predominantly regional in-migrants, often living in isolated fishing camps (or economic enclaves) where capture, processing and trading activities occur. This paper explores the factors driving the fishing camp formation, relations with non-camp communities and interactions with prominent authority groups. One camp, presented here in the context of an anthropological case study, lost access to Ancopado beach during the designation of Orango National Park. Following violent evictions, migrant fishers shifted their efforts into less-observed waters, introducing challenging power negotiations with indigenous Bijagós islanders and fisheries authorities. Fishing persists inside the marine protected area, indicative of non-compliance by small-scale fishers who continue to resist a weak resource management agenda. The implications of this situation are discussed in terms of human rights to fish.
\end{abstract}

Keywords Guinea-Bissau, human rights, marine protected area, Orango National Park, resource management, smallscale fishing

\section{Introduction}

Taced with dwindling catch rates and increasingly com- plex regulations (Urquhart et al., 2013) the challenges confronting small-scale fishing communities cannot be ignored (Chuenpagdee, 2012). The Voluntary Guidelines upheld by the FAO Committee of Fisheries and supported by 4,00o individuals from state, civil society and NGOs herald a new era of participatory, ecosystem-friendly small-scale fishing policies, strategies and frameworks (FAO, 2014a). Defining rights to fish is a contentious issue and, with political developments still in their infancy, many problems in the implementation process are yet to be resolved (Jentoft, 2014).

Although $>90 \%$ of all fishers are involved in small-scale fishing $(\mathrm{FAO}, 2014 \mathrm{~b})$ the sector is largely managed using conventional approaches, which support effort-control

HeLEn Cross (Corresponding author) 14 Burnside Road, Uphall, West Lothian, EH52 5DE, UK. E-mail ucsahcc@ucl.ac.uk

Received 13 June 2014. Revision requested 28 August 2014.

Accepted 13 March 2015. First published online 26 November 2015. through privatization and allocation of fishing rights (Capistrano \& Charles, 2012). Rights-based fishing, as supported, for example, by the World Bank Global Partnership for Oceans initiative, aims to improve unsustainable practices by restricting licence allocation and access to fishing areas. Advocates insist that limiting rights will provide economic incentives for collective self-regulation (Berkes, 2006), ensuring fisheries are managed for the future (Capistrano \& Charles, 2012). However, small-scale fishing activities predominate in developing countries, where both the state of fish stocks and sea tenure arrangements are poorly understood (Branch et al., 2012; Stevens et al., 2014). This complicates the rights-based fishing approach, as understanding who should be allowed to catch which fish from where is not a clear-cut issue. Fisheries are commonly viewed as fundamental to livelihoods, particularly of the poor. Access to small-scale fishing is often critical to welfare (Béné, 2011) and well-being (Coulthard et al., 2011; Weeratunge et al., 2014), particularly in remote communities with inadequate health-care services, low levels of education, lack of access to land, poor infrastructure, minimal access to micro credit, little political free will, and increased susceptibility to HIV and AIDS-related illnesses (Allison \& Seeley, 2004). Critics of rights-based fishing therefore argue that economic incentives for resource stewardship are insufficient when there are other sources of insecurity in people's lives unrelated to fisheries (Allison et al., 2012). Moving beyond property rights to a human rights approach to fishing is viewed as a way of improving both human development and resource sustainability (Ratner et al., 2014).

Marine protected areas (MPAs) serve various purposes but commonly are designed to restrict access, control fishing effort or prevent biodiversity loss (Mascia \& Pailler, 2011; Angulo-Valdés \& Hatcher, 2010; Jentoft et al., 2011; Jennings et al., 2014). Benefits to fisheries are particularly evident in no-take zones (Lester \& Halpern, 2008; Halpern et al., 2009). There have been numerous calls to increase global MPA coverage (Caveen et al., 2013); for example, the strategic plan agreed in 2010 at the 1oth Conference of the Parties of the Convention on Biological Diversity, in Nagoya, Japan, outlines 20 goals. Aichi Target 11 in particular aims to achieve conservation through limiting use within $10 \%$ of coastal and marine areas by 2020 (Woodley et al., 2012; Bennett \& Dearden, 2014). Marine protected areas can facilitate an increase in species diversity 
(Gell \& Roberts, 2003) and replenishment of fish stocks (Hilborn et al., 2004), and they can protect ecosystem structure and enhance resilience, increasing adaptive capacity and reducing risks during extreme climatic events (MacKinnon et al., 2011). They may lead to improved governance and alternative livelihoods; encourage economic growth through tourism (Rodwell \& Roberts, 2004); provide social, educational and cultural benefits; and provide control sites for scientific research (Agardy et al., 2011). However, MPAs may also be subject to inappropriate planning and mismatching of international or national objectives with local interests (Angulo-Valdés \& Hatcher, 2010; Benson, 2012; Cohen \& Foale, 2013). In countries with low human development scores, government structures are inherently weak (Gutiérrez et al., 2011). Here, both small and poorly designed MPAs are particularly susceptible (Mora \& Sale, 2011; Song et al., 2013) to social failings (Christie, 2011) and oversights, such as marginalization (Agrawal \& Redford, 2009) or omission (Crona \& Rosendo, 2011) of key resource user-groups. In these circumstances it is not self-evident that MPAs are more favourable than traditional fisheries management tools (Warner \& Pomeroy, 2012; Caveen et al., 2013). In reality, MPAs are subject to non-compliance, encroachment, opportunistic behaviour and resourcerelated conflict (Fabricius et al., 2007), particularly where societal, economic, cultural and institutional characteristics are overlooked (Charles \& Wilson, 2009). I investigate complexities at the interface between protected areas, fisheries management and commercial small-scale fishing operations in the Bijagós region of Guinea-Bissau, and attempt to inform the design of fishing regulation.

\section{Study area}

Development in Guinea-Bissau (Fig. 1) has been hindered by political rivalry. Assassinations, periodic coups d'état and civil war have left an estimated $88 \%$ of the country's largely rural population surviving on disposable income of $<$ USD 1 per day (Gacitua-Mario et al., 2007), and national unemployment remains high (Cockayne \& Williams, 2009). Territorial waters, coinciding with the meeting of the Canary and Guinea currents, serve offshore industrial fishing, including illegal, unregulated and unreported activities, driven by increasing export demands and high prices for seafood (Kaczynski \& Looney, 2000; Kaczynski \& Fluharty, 2002; Agnew et al., 2009). In the near-shore, thousands of workers are employed directly or supported by small-scale fishing economies (González, 2010). The intensity of small-scale fishing is such that monitoring and management are considered outside government control (Agnew et al., 2010; González, 2010). For a fish-dependent nation experiencing high rates of child mortality and malnutrition, protein security is a key challenge (Kawarazuka \& Béné, 2011).
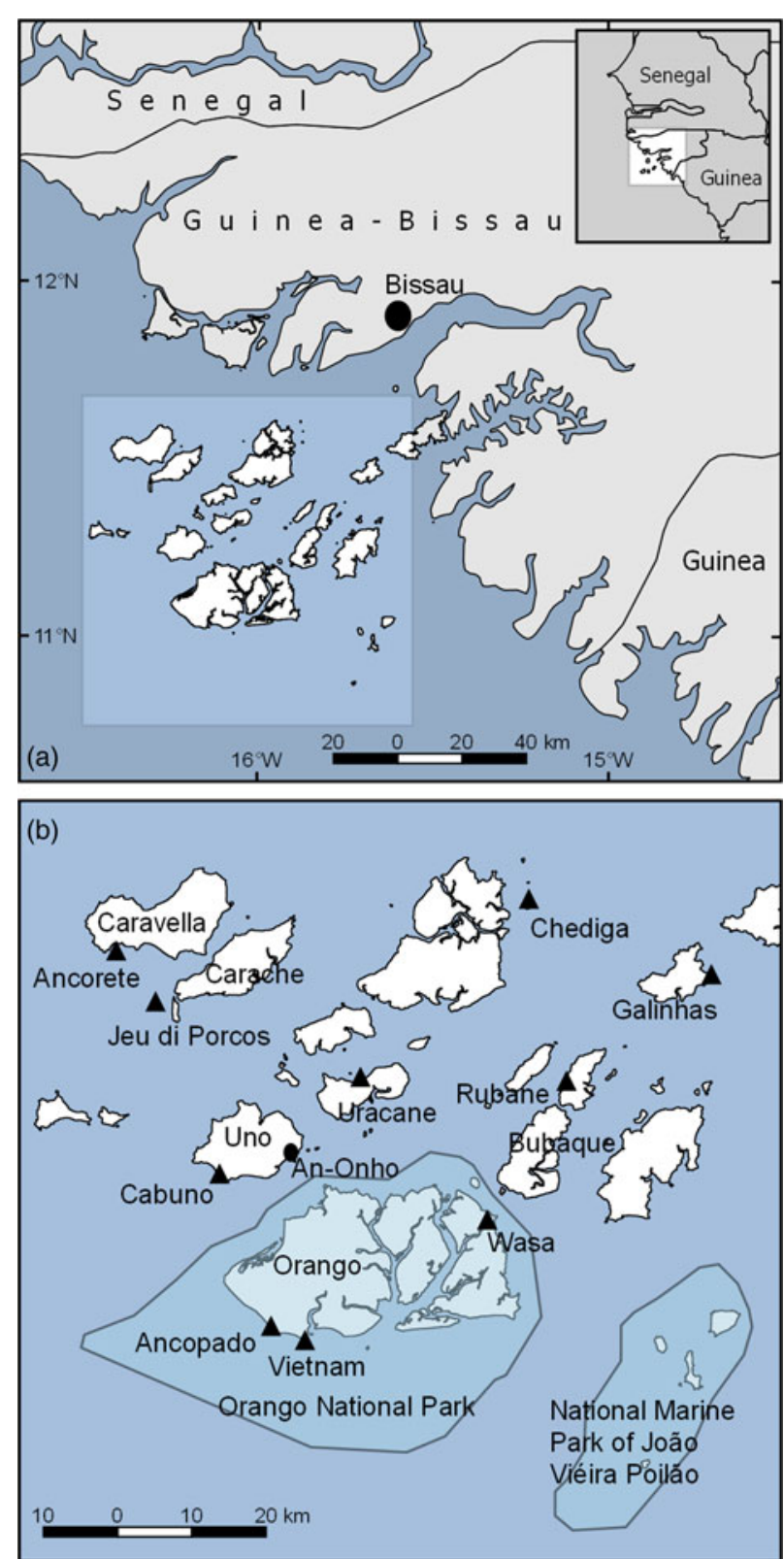

FIg. 1 (a) The Bijagós Archipelago, Guinea-Bissau, with the boundaries of the UNESCO Biosphere Reserve including Orango National Park (PNO) and the National Marine Park of João Viéira Poilão (PNM-JVP). (b) Key fishing camps (past and present) in the Bijagós Archipelago, as described by residents of Cabuno camp, Uno Island, in 2010.

The Bijagós ethnic group occupies some 20 islands in the Bijagós Archipelago (West Africa's only coastal island system), setting others aside as sacred, or for seasonal agriculture or grazing. Many Bijagós follow an animistic religion, led by traditional priests. They believe in 'another world' guarded by sacred spirits (imbued into the physical bodies of animals and trees) who control both individual and collective destinies. Ceremonial masks celebrating animist spirits (and inadvertently biodiversity itself) are routinely paraded in Bijagós rituals, and the active promotion of sound relations between 
TABLE 1 The prices (in CFA and GBP) of fishing licences for national and non-national small-scale fishers in Guinea-Bissau in 2010

\begin{tabular}{llc}
\hline Licence type & Citizen status & Price, CFA (GBP) \\
\hline Paddle boat & National & $30,000(60)$ \\
& Non-national & $50,000(100)$ \\
15 horse power engine & National & $84,000(168)$ \\
& Non-national & $175,000(350)$ \\
40 horse power engine & National citizen & $180,000(360)$ \\
& Non-national & $300,000(600)$ \\
\hline
\end{tabular}

the present and spirit world is considered fundamental to Bijagó well-being (Maretti, 2003). As a conservation measure, the islands were designated a UNESCO Biosphere Reserve in 1996, and 4 years later both the National Marine Park of João Vieira Poilão (NMP-JVP) and Orango National Park (PNO) were established as IUCN Management Category II protected areas, for ecosystem protection and for recreation (Campredon \& Cuq, 2001; Catry et al., 2009). The protection agenda coincided with a move to reign in small-scale fishing efforts, identified as a threat to marine megafauna (Broderick et al., 1998). Small-scale fishing activities have proliferated in the Bijagós Archipelago for decades, involving multinational migrants whose aspirations and realities differ from those of indigenous islanders (Tvedten, 1990; Haakonsen, 1991; Baekgaard \& Overballe, 1992; Campredon \& Cuq, 2001; Randall, 2005; Diop \& Dossa, 2011; Binet et al., 2012). Fishers, traders, fish-smokers and transporters originating from across West Africa settle within or pass through fishing camps (economic enclaves) dispersed across the islands and along the mainland coast. These camps provide a backbone to the wider regional small-scale fishing economy. GuineaBissau, however, unlike neighbouring states, charges higher tariffs for non-national fishing licences (Diaw \& Haakonsen, 1992; Table 1) and this creates a specific dilemma: small-scale commercial fishing activity may threaten biodiversity but it is also valuable (given the expensive licenses required).

Uno Island (c. $100 \mathrm{~km}^{2}$ ) hosts an indigenous population of c. 3,000, in 27 villages (known in Portuguese Kriole as tabancas). Conditions on the island are basic, with no electricity, running water or roads. Uno was selected for this study because of the presence of an in-migrant small-scale fishing camp, in Cabuno, and hence the potential for cross-cultural comparison. For the Bijagós of Uno, subsistence rice production is a central occupation, complemented by subsistence fishing, cashew (cash crop) harvesting and livestock herding. Agricultural practice is closely tied to customary land law and an age-based initiation society structure. In contrast, residents of the small-scale fishing camp originate from several West African countries and diverse occupational backgrounds (Cross, 2015a). Sun-drying, smoking and salting techniques are all adopted, depending on the type of fish caught (Cross, 2015b) and the market destination, of which multiple examples between Dakar and Lagos were cited.

\section{Methods}

Data are derived from 24 months of fieldwork on Uno Island. A pilot visit (April-June 2008) and follow-up trip (January 2009-September 2010) were temporarily disrupted by the assassination of President Joao-Bernardo de Vieira, in Bissau city, in March 2009. During fieldwork a variety of methods (household, economic, spot-check time allocation and catch landing surveys; participant observation; semistructured interviews; focus groups; and key informant discussions) were trialled and developed on Uno, to undertake a cross-cultural investigation of the livelihoods of migrant small-scale fishers and Bijagós islanders (Cross, 2014).

Semi-structured life-history interviews were conducted with 142 individuals: 83 Bijagós residents of the Cabuno area and 59 residents of the small-scale fishing camp. Research assistants were employed to undertake documentation, and during separate methodological trials key events were identified as benchmarks or prompts to frame each individual history. These included political milestones and episodes of conflict, but also crop-raiding events and initiation ceremonies identified by the Bijagós villagers. Bijagós assistants conducted interviews in the villages (in either Bijagó or Portuguese Kriole); a migrant assistant conducted interviews in the camp in various languages (including Mandinga, Soussou and Temne). Follow-up meetings were held regularly with each assistant, providing an opportunity to read through, discuss, transcribe and translate each interview into English. All respondents were invited to participate through a purposive snowball sampling technique (Bunce et al., 200o). Life history interviews comprised three sections, the first detailing the participant's core characteristics (year of birth/age, name, gender, birthplace, ethnicity, religion, nationality, household membership, education status and current occupation), the second focusing on occupational experience within and outside the fishing industry (and reasons for occupational change), and the third discussing occupational experiences in fisheries more specifically (detailing locational information, catch types and conditions of payment).

The life history interviews are used here to contextualize historical, social, economic and cultural knowledge (Davis, 2006) surrounding small-scale fishing in the Bijagós. Face-to-face interviews grant freedom to respondents, encouraging confidence and minimizing the gap between interviewee and researcher (Zappes et al., 2013). Data derived from these interviews provide a biographical means (Ritchie et al., 2014) of exploring the wider context of fishing to participants. Narratives, thoughts, comments and opinions of interview participants were pooled in a thematic analysis (Braun \& Clarke, 2006), and I present here a chronology of events as recalled by interviewees. These dialogues 
provide a platform from which to investigate circumstances surrounding the formation of small-scale fishing camps, and relations with non-camp communities.

\section{Results}

\section{Formation of the Cabuno camp (1990-2000)}

Many migrant small-scale fishers working on Uno first settled in the archipelago during the late 1990s, before the UNESCO accreditation. One camp, known in Kriole as Jeu di Porcos (Pig Island), was then flourishing, providing numerous opportunities for trade (Fig. 1b). This island was set aside by the Bijagós of Caravella for pig grazing. Migrant workers, many lacking fishing experience, arrived from the mainland; Senegalese fishers also arrived from Jeu di Peixe (Fish Island). Many Senegalese were established in the fishing business, progressing from crew members to net owners or captains on motorized vessels, sponsored by wealthy investors from Ziguinchor. With motorized vessels they could work further afield, and the archipelago presented bounteous opportunities for fishing. Jeu di Porcos had a population of several hundred people, and conditions were basic. During the November-May dry season, drinking water was extracted from neighbouring Caravella and sold in the camp. With a constant influx of new arrivals from both the north (Senegal) and south (Guinea-Conakry, Sierra Leone and Liberia), competition for fishing and living space intensified. Motorized boats began to work further south and gradually Orango Island became a popular area. Moving daily between Jeu di Porcos and Orango was costly, however, in terms of both time and petrol. By the year 2000 , many groups had relocated permanently to Imbone, in southern Orango, where two small-scale fishing camps were established (Ancopado and Vietnam).

According to the small-scale migrant fishers on Uno Island, as legislation was finalized for Orango National Park, fishers from Jeu di Porcos who had resettled on Orango met with forceful resistance. Armed members of the Commission for Fisheries Surveillance, a subsection of the Fisheries Ministry, forcibly dismantled Ancopado and Vietnam, burning houses, stores and fishing materials. As one angry respondent described it, 'That place is a zoo! There the politicians like to keep everything perfect and not have no fishing man touch nothing.' Following eviction from Orango, the migrant fishers returned to Jeu di Porcos, where they were joined by new arrivals from the mainland. Over the following months conditions in the camp became more crowded. Already depleted mangroves were cut back even further, providing fuel for cooking and smoking fish. Eventually the camp was destroyed by a storm. With their homes in ruins, many occupants relocated to nearby Caravella Island, others went south and many arrived on the beach of Cabuno.

\section{Relations with non-camp communities (2000-2008)}

Bijagós in Cabuno still recall the 1980s, before any small-scale fishers arrived. Several described the use of a sacred grove for animistic marriage rituals. A friendly rapport was then established with passing fishers; exchanges of news and knowledge were welcomed, and trading opportunities realized. Following the violence at Vietnam, the Orango eviction and the collapse of Jeu di Porcos, several hundred fishers arrived and relations with the Bijagós deteriorated. With the migrant fishing population increasing, catching extensively and showing little sign of moving on, the people of Cabuno walked out to the beach. 'We begged them to leave here,' explained one islander, 'because of what was happening to our sea.' The Bijagós maintain that any yearround fishing effort is undesirable and an 'improper cultivation' of the sea. 'In the time of working the rice paddies,' one respondent explained, 'we come onto the land and we work. But those people, they are at sea every day. For us, we have different types of work. We don't only fish.' Many indicated their frustration at this extensive effort, 'because of tomorrow'. Extensive clearance of forest and mangrove habitat on Uno (for cooking and fish-smoking purposes) has generated anger and fear among the islanders for the existence of their sacred ritual spaces, most notably those used during the secret initiation ceremony. 'If they (the migrants) start to destroy our initiation sites with their tree-cutting,' one villager explained, 'then they will destroy the heritage of our villages. In the beginning, they respected the terrain of the village. But now, this is their terrain. This camp is more permanent. The people have begun staying longer. They don't listen to the voice of the village.'

The Bijagós and migrant small-scale fishers in Cabuno now share a history of violent conflict. During the dry season of 2003 a cohort of Bijagós male pre-initiates from Cabuno stormed and burned the fishing camp. The attack took place in broad daylight and the perpetrators stood their ground as the fire spread. Unsure what to do the fishers fled, some by boat, many on foot. 'We sailed north around Uno,' one Sierra Leonean explained, 'and we begged one village to let us camp on their beach but they refused.' The fishers regrouped at the police office near An-Onho, where they were advised to return to Cabuno beach. Angered by the forceful intervention by the Bijagós, the Island Administration quickly seized control of the situation. This authority (composed of mainland ethnicities) perceived the Bijagós as having no right to destroy or evict fishers from national land. Various regulatory and organizational mechanisms were then used to facilitate the return of migrant fishers to Cabuno. The Ministry of Transport and Communications assumed control of the landing area in Cabuno, and the Maritime Police took responsibility for monitoring access to and through the fishing camp, assisted by the island police unit. Rights to land catch within the 
camp area fell under the control of the Fishing Ministry, and wood cutting licences under the Department of Forestry (Ministry of Agriculture).

With this shift in power, a split emerged among the Bijagós. Elders in Cabuno who accepted State intervention were criticized as being weak. Bijagó youth in particular were critical. 'It's because all the elders were sitting with all the power. They turned to us youngsters, saying "leave those people in the beach alone", and that is how the problem has come back again. In the older times, responsibility was always given to the elders but their ways of understanding are not complete; youngsters now also have to take part.' Some elders also regretted the administrative control. 'The State is the only one to benefit,' one individual explained. 'According to the administration, the migrants must stay. But then they (the State) are the ones going there every month to collect money.' Given the substantial financial opportunities presented by non-national small-scale fishing, the camp is subject to frequent and impromptu visits by the Uno Island administration, fisheries officers on Uracane and Bubaque, inspectors from Bolama and Bissau, the national maritime police, immigration officers and the Commission for Fisheries Surveillance. If migrant residents are found without identity papers, boat certification, fishing licences or wood cutting permits, irregular on-the-spot fines are issued.

In response, small-scale fishers have adopted various strategies to manage individual circumstances. Any occupants possessing a Guinea-Bissau national identity card (purchased in the capital) may offer services such as signing for boat licences or fishing documents, to avoid the higher non-national rates. Alternatively migrants may simply hide in the bush during inspections. Fishing boats are often hidden in the surrounding mangroves, and stocks of smoked or salted fish and valuable household possessions are concealed to avoid theft or confiscation by fisheries inspectorates. If inspectors are present, camp residents stand on the beach front and warn any approaching boats not to land. News of imminent inspections is communicated by means of a network that includes passing fishing boats and traders. Independent visits from the Bijagós are also common, with local residents asking for compensation against wood cutting activities. However, these requests are largely ignored.

\section{Discussion}

Ethnographic case studies facilitate an in-depth understanding of phenomena occurring within a relatively natural setting (Bhattacharya, 2012) and knowledge may be accumulated from verbal statements and daily observations of events as they occur naturally (Bernard, 2006). Knowledge of small-scale fishers in the Bijagós, as captured here through life-history interviews, is insufficient to fully evaluate the social and ecological implications of fishing area restrictions around Uno. However, attempts are now being made to assess the challenges, based on anecdotal and comparative evidence (Igoe \& Brockington, 2007).

Instances of forceful (Agrawal \& Redford, 2009) and socially unjust (De Santo, 2013) conservation-induced displacement episodes have been described (Igoe \& Brockington, 2007; Schmidt-Soltau \& Brockington, 2007; Miller et al., 2012), associated with ill-treatment (Almudi \& Berkes, 2010) and violence (Peluso, 1993). Migrant small-scale fishers on Uno discussed a militaristic eviction from southern Orango that coincided with the designation of Orango National Park. This resulted in a loss of control and displacement of fishing, from a restricted-use to unrestricted area. Ill-considered marine management is known to merely displace fishing, causing widespread change or damage in formerly undisturbed habitats (Kaiser, 2005; Ewers \& Rodrigues, 2008; Crona \& Rosendo, 2011), and effective management requires efforts to be made beyond spatial boundaries (Allison et al., 1998). The finding that protected area status alone cannot ensure protection is not new (Teh \& Sumaila, 2013); Fernandes (2012) observed that conservation rules in the Bijagós Archipelago were poorly understood by small-scale fishers. Evidence from Uno reveals that fishing in the Bijagós is poorly regulated. Restrictions and closures are required for biodiversity conservation but fishing can prevail within protected areas and leak into unprotected environments. Small-scale fishing is generally viewed as problematic on the islands, ultimately increasing both the vulnerability of the camps and the potential for conflict with adjacent Bijagós communities. As small-scale fishing economies in the archipelago remain isolated, the need to reform rights to fish remains and the welfare functions of small-scale fishing remain underestimated.

Alienation of resource users (Hind et al., 2010), prioritization of NGO donor goals above local needs (Benson, 2012), tendencies to undermine local access to development (Bennett \& Dearden, 2014), and inattention to alternative livelihood pathways (Bown et al., 2013) limit support for marine protected areas. Increased conflict is common where protected areas are viewed as problematic (Bavinck, 2005). Considering those gaining and losing rights on Uno (an approach advocated by Mascia \& Claus, 2009), both small-scale fishers and indigenous islanders have felt disempowered since the designation of Orango National Park. Conversely, the Uno island administration, fisheries officers, maritime police units, immigration officers, the Commission for Fisheries Surveillance and Department of Forestry representatives from Uracane, Bubaque and Bissau all appear to be vying for a stake in the control of small-scale fishing, while implementing a relatively ad hoc management initiative.

Industrial fishing licence payments are a critical source of revenue in Guinea-Bissau (Kaczynski \& Fluharty, 2002; 
Agnew et al., 2010); the potential profits generated from non-national small-scale fishers is reflected on Uno Island. In both large and small-scale fishing arenas substantial losses may result from mismanagement. By 2010 residents of the Uno fishing camp had realized their greatest vulnerability: foreignness. The migrants openly discussed the significance of payments demanded by officials legitimately charged with controlling fishing. Migrant fishers are aware of the opportunity their presence offers these officials to supplement inadequate, diverted, lost or unpaid salaries. Numerous examples of corruption, involving both officials and fishers, were described in the Uno interviews, including false identity papers, boat licence fraud, acceptance of unregistered fines, and confiscation of personal goods by State authorities. This study presents a crisis in which rent-seeking and resource-rent appropriation, weak institutional performance and political short-termism (Kaiser, 2005; Béné, 2008; Baggio \& Papyrakis, 2010; Béné et al., 2010; Sumaila et al., 2010) obstruct the interface between fisheries, protected area management and conservation in the Bijagós. From a government perspective, control of small-scale fishing seems an insurmountable challenge given the inherent corruption. Non-compliance, conflict and non-cooperation are likely to present persistent problems, with negative consequences for the livelihoods of those dependent upon fish. The political systems involved are complex and founded upon multiple conflicting objectives, which fundamentally jeopardizes any reform process (Cross, 2014).

In considering options for improving small-scale fisheries, movement towards a collaborative co-management agenda could foster support. If co-management is not seen as a silver bullet (Nielson \& Lund, 2012) or blueprint (Defeo et al., 2014) it can engage with a desire for reform, through participatory democracy, decentralization, social engagement and community empowerment (Charles \& Wilson, 2009; Christie, 2011; Nunan, 2014). Collaboration does, however, increase the risk of marginalization (Jentoft, 2005) and modification of an existing status quo among resource users (Béné, 2011; Njaya et al., 2012). Integrating local ecological with conventional scientific knowledge can encourage shared responsibility (Berkes, 2010), and compiling location-specific objectives may foster institutional diversity and political will (Jones et al., 2013; Carbonetti et al., 2014). Although inclusion of migrants in collaborative plans is generally low (Cinner et al., 2009; Fulanda et al., 2009), co-management seeks to increase resilience and develop incentives for collaboration, by nurturing marine stewardship (Levin \& Lubchenco, 2008) and encouraging compliance (Mwaipopo, 2008; Slater et al., 2014). Arguably, new collaborative institutions can only succeed if they absorb the tacit knowledge accumulated from historically deep-rooted local institutions, building upon existing cultural norms and meanings associated with various types of local leadership, social networks, reciprocal obligations, and the routines of everyday life (Cleaver, 2002; Jentoft, 2005; Gutiérrez et al., 2011; Russell \& Dobson, 2011). In Kenya the involvement of fishers in community organization and decision making has challenged notions that small-scale fishers are poorly organized (Cinner et al., 2010). Likewise in Australia the Girringun Aboriginal Corporation, which represents the land and sea interests of traditional owner groups, has achieved recognition in decision making for the Great Barrier Reef World Heritage Centre through a persistent positive commitment to collaborative management (Nursey-Bray \& Rist, 2009).

A Biodiversity Conservation Trust Fund (the Bioguinea Foundation) currently controls financial operations within Guinea-Bissau's National Parks (GEF, 2012) and supports an increase in protected area coverage (CFA, 2010). Marine megafauna (particularly elasmobranchs, cetaceans, sea turtles and swordfishes) continue to attract attention in the Bijagós Archipelago as conservation research assimilates the knowledge of local fishers (Tous et al., 1998; Béziers, 2009; Leeney \& Poncelet, 2015; Leeney et al., 2015). The small-scale marine fishing sector in Guinea-Bissau persists in providing employment for more than 120,000 people (Belhabib \& Pauly, 2015) while securing a basic but critical staple food for the wider population. The right to fish, however, remains a contentious issue (Borrini-Feyerabend \& Hill, 2015) and migrant fishers do not yet appear to be represented.

\section{Acknowledgements}

This study was funded by a joint ESRC-NERC interdisciplinary studentship (ES/Foo9984/1), the Parkes Foundation, the University College London (UCL) Graduate School and UCL Fellowship Fund. I extend sincere thanks to Katherine Homewood and Caroline Garaway (UCL Anthropology) and Marcus Rowcliffe (Institute of Zoology, London) for supervisory guidance, and to Eddy Allison, JoAnn McGregor and the anonymous reviewers of this article. Finally, I thank all field assistants and residents of Uno Island for their hospitality and generosity of time in sharing these experiences.

\section{References}

Agardy, T., Notarbartolo di Sciara, G. \& Christie, P. (2011) Mind the gap: addressing the shortcomings of marine protected areas through large scale marine spatial planning. Marine Policy, 35, 226-232.

Agnew, D.J., Pearce, J., Pramod, G., Peatman, T., Watson, R., Bedington, J.R. \& Pitcher, T.J. (2009) Estimating the worldwide extent of illegal fishing. PLoS ONE, 4(2), e4570.

Agnew, D.J., Walmsley, S.F., Leotte, F., Barnes, C., White, C. \& Good, S. (2010) Africa Regional Fisheries Project: Estimation of the Cost of Illegal Fishing in West Africa. Final Report. Http:// livebettermagazine.com/eng/reports_studies/pdf/Estimation_of_ 
The_Cost_of_Illegal_Fishing_in_West_Africa_Final_report_ 20100513.pdf [accessed 4 January 2015].

Agrawal, A. \& Redford, K. (2009) Conservation and displacement: an overview. Conservation and Society, 7, 1-10.

Allison, E.H. \& SeELEy, J.A. (2004) HIV and AIDS among fisherfolk: a threat to 'responsible fisheries'? Fish and Fisheries, 5, 215-234.

Allison, E.H., Ratner, B.D., Asgard, B., Willmann, R., Pomeroy, R. \& Kurien, J. (2012) Rights-based fisheries governance: from fishing rights to human rights. Fish and Fisheries, 13, 14-29.

Allison, G.W., Lubchenco, J. \& Carr, M.H. (1998) Marine reserves are necessary but not sufficient for marine conservation. Ecological Applications, 8, S79-S92.

Almudi, T. \& Berkes, F. (2010) Barriers to empowerment: fighting eviction for conservation in a southern Brazilian protected area. Local Environment, 15, 217-232.

Angulo-Valdés, J.A. \& Hatcher, B.G. (2010) A new typology of benefits derived from marine protected areas. Marine Policy, 34, 635-644.

Baekgaard, M. \& Overballe, H. (1992) When is a fishing man a fisherman? Artisanal fishery development in Guinea-Bissau. In Fishing for Development (eds I. Tvedten \& B. Hersoug), pp. 173-19o. Nordiska Afrikainstitutet, Uppsala, Sweden.

BAGGIO, J.A. \& PAPYRAKIS, E. (2010) Ethnic diversity, property rights, and natural resources. The Developing Economies, 48, 473-495.

B AVINCK, M. (2005) Understanding fisheries conflicts in the South-a legal pluralist perspective. Society \& Natural Resources, 18, 805-820.

Belhabib, D. \& Pauly, D. (2015) Fisheries in troubled waters: a catch reconstruction for Guinea-Bissau, 1950-2010. Working Paper \#2015-72. Fisheries Centre, University of British Columbia, Vancouver, Canada.

Béné, C. (2008) Global Change in African Fish Trade: Engine of Development or Threat to Local Food Security. OECD Food, Agriculture and Fisheries Papers, No. 10.

BÉNÉ, C. (2011) CAADP and fisheries policy in Africa: are we aiming for the right reform? Future Agricultures Policy Brief o4o. Http:// www.future-agricultures.org/publications/research-and-analysis/ 1417-caadp-and-fisheries-policy-in-africa-are-we-aiming-for-theright-reform/file [accessed 9 July 2015].

Béné, C., Hersoug, B. \& Allison, E.H. (2010) Not by rent alone: analysing the pro-poor functions of small-scale fisheries in developing countries. Development Policy Review, 28, 325-358.

Bennett, N.J. \& DeARden, P. (2014) Why local people do not support conservation: community perceptions of marine protected area livelihood impacts, governance and management in Thailand. Marine Policy, 44, 107-116.

Benson, C. (2012) Conservation NGOs in Madang, Papua New Guinea: understanding community and donor expectations. Society \& Natural Resources, 25, 71-86.

Berkes, F. (2006) From community-based resource management to complex systems: the scale issue and marine commons. Ecology and Society, 11, 45 .

Berkes, F. (2010) Devolution of environment and resources governance: trends and future. Environmental Conservation, 37, 489-500.

Bernard, H.R. (2006) Research Methods in Anthropology: Qualitative and Quantitative Approaches. AltaMira Press, Walnut Creek, USA.

BÉziers, P. (2009) Poisson-Scie Guinée Bissau In Rapport de stage: Mise en place des activités de collecte des données, et de conservation. Http://www.noeconservation.org/imgs/bibliotheque_fichier/ 090813131759_2009-rpt-p-beziers.pdf [accessed 9 July 2015].

Bhattacharya, S. (2012) The effectiveness of the ISM Code: a qualitative enquiry. Marine Policy, 36, 528-535.
Binet, T., Failler, P. \& Thorpe, A. (2012) Migration of Senegalese fishers: a case for regional approach to management. Maritime Studies, 11, 1-15.

Borrini-Feyerabend, G. \& Hill, R. (2015) Governance for the conservation of nature. In Protected Area Governance and Management (eds G. L. Worboys, M. Lockwood, A. Kothari, S. Feary \& I. Pulsford), pp. 169-206. ANU Press, Canberra, Australia.

Bown, N.K., Gray, T.S. \& STEAD, S.M. (2013) Co-management and adaptive co-management: two modes of governance in a Honduran marine protected area. Marine Policy, 39, 128-134.

Branch, T.A., Austin, J.D., Acevedo-Whitehouse, K., Gordon, I.J., Gompper, M.E., Katzner, T.E. \& Pettorelli, N. (2012) Fisheries conservation and management: finding consensus in the midst of competing paradigms. Animal Conservation, 15, 1-3.

Braun, V. \& Clarke, V. (2006) Using thematic analysis in psychology. Qualitative Research in Psychology, 3, 77-101.

Broderick, A.C., Catry, P.X. \& Araujo, A. (1998) A Proposal of a Strategy for the Conservation of Marine Turtles in Guinea-Bissau. Marine Turtle Research Group, University of Exeter, Penryn, UK.

Bunce, L., Townsley, P., Pomeroy, R. \& Pollnac, R. (200o) Socioeconomic Manual for Coral Reef Management. Global Coral Reef Monitoring Network, ICRI Secretariat, Ministry of the Environment, Tokyo, Japan.

Campredon, P. \& CuQ, F. (2001) Artisanal fishing and coastal conservation in West Africa. Journal of Coastal Conservation, 7, 91-100.

Capistrano, R.C.G. \& Charles, A.T. (2012) Indigenous rights and coastal fisheries: a framework of livelihoods, rights and equity. Ocean \& Coastal Management, 69, 200-209.

Carbonetti, B., Pomeroy, R. \& Richards, D.L. (2014) Overcoming the lack of political will in small scale fisheries. Marine Policy, 44, 295-301.

Catry, P., Barbosa, C., Paris, B., Indjai, B., Almeida, A., Limoges, B. et al. (2009) Status, ecology, and conservation of sea turtles in Guinea-Bissau. Chelonian Conservation and Biology, 8, 150-160.

Caveen, A.J.Gray, T.S., Stead, S.M. \& Polunin, N.V.C. (2013) MPA policy: what lies behind the science? Marine Policy, 37, 3-10.

CFA (2010) Joining Forces: The Dakar Meeting of African Environmental Funds. Conservation Finance Alliance.

Charles, A. \& Wilson, L. (2009) Human dimensions of Marine Protected Areas. ICES Journal of Marine Science, 66, 6-15.

Christie, P. (2011) Creating space for interdisciplinary marine and coastal research: five dilemmas and suggested resolutions. Environmental Conservation, 38, 172-186.

Chuenpagdee, R. (2012) Global partnership for small-scale fisheries research: too big to ignore. SPC Traditional Marine Resource Management and Knowledge Information Bulletin, 12, 22-25.

Cinner, J.E., Fuentes, M.M.P.B. \& Randriamahazo, H. (2009) Exploring social resilience in Madagascar's marine protected areas. Ecology and Society, 14, 41.

Cinner, J.E., McClanahan, T.R. \& Wamukota, A. (2010) Differences in livelihoods, socioeconomic characteristics, and knowledge about the sea between fishers and non-fishers living near and far from marine parks on the Kenyan coast. Marine Policy, 34, 22-28.

Cleaver, F. (2002) Reinventing institutions: bricolage and the social embeddedness of natural resource management. The European Journal of Development Research, 14, 11-30.

Cockayne, J. \& Williams, P. (2009) The Invisible Tide: Towards an International Strategy to Deal with Drug Trafficking Through West Africa. International Peace Institute, New York, USA.

Cohen, P.J. \& FoAle, S.J. (2013) Sustaining small-scale fisheries with periodically harvested marine reserves. Marine Policy, 37, 278-287. 
Coulthard, S., Johnson, D. \& McGregor, J.A. (2011) Poverty, sustainability and human wellbeing: a social wellbeing approach to the global fisheries crisis. Global Environmental Change, 21, 453-463.

Crona, B. \& Rosendo, S. (2011) Outside the law? Analysing policy gaps in addressing fishers' migration in East Africa. Marine Policy, $35,379-388$.

Cross, H. (2014) The importance of small-scale fishing to rural coastal livelihoods: a comparative case-study in the Bijagós Archipelago Guinea-Bissau. PhD thesis. Department of Anthropology, University College London, UK.

Cross, H. (2015a) Why fish? Using entry-strategies to inform governance of the small-scale sector: a case-study in the Bijagós Archipelago (West Africa). Marine Policy, 51, 128-135.

Cross, H. (2015b) Elasmobranch capture by commercial small-scale fisheries in the Bijagós Archipelago, Guinea Bissau. Fisheries Research, 168, 105-108.

Davis, P. (2006) Poverty in time: Exploring poverty dynamics from life history interviews in Bangladesh. In Workshop on Concepts and Methods for Analysing Poverty Dynamics and Chronic Poverty, 23-25 October 2006. University of Manchester, UK.

De Santo, E.M. (2013) Missing marine protected area (MPA) targets: how the push for quantity over quality undermines sustainability and social justice. Journal of Environmental Management, 124, 137-146.

Defeo, O., Castrejón, M., Pérez-Castañeda, R., Castilla, J.C., Gutiérrez, N.L., Essington, T.E. \& Folke, C. (2014) Comanagement in Latin American small-scale shellfisheries: assessment from long-term case studies. Fish and Fisheries, http:// dx.doi.org/10.1111/faf.12101.

Diaw, C. \& Haakonsen, J.M. (1992) Report on the Regional Seminar of Artisanal Fishermen's Migrations in West Africa Programme for Integrated Development of Artisanal Fisheries in West Africa. FAO Technical Report IDAF/WP/42, FAO, Rome, Italy.

Diop, M. \& Doss A, J. (2011) 30 Years of Shark Fishing in West Africa. Fondation Internationale du Banc d'Arguin, Morges, Switzerland.

Ewers, R.M. \& Rodrigues, A.S.L. (2008) Estimates of reserve effectiveness are confounded by leakage. Trends in Ecology and Evolution, 23, 113-116.

Fabricius, C., Folke, C., Cundill, G. \& Schultz, L. (2007) Powerless spectators, coping actors and adaptive co-managers: a synthesis of the role of communities in ecosystem management. Ecology and Society, 12, 29.

FAO (2014a) Voluntary Guidelines for Securing Sustainable Small-Scale Fisheries in the Context of Food Security and Poverty Eradication. Http://www.fao.org/cofi/42011-od2bdfc444f1413oc4c13ecb44218c 4d6.pdf [accessed 25 November 2014].

FAO (2014b) The State of World Fisheries and Aquaculture: Opportunities and Challenges. FAO, Rome, Italy.

Fernandes, R.M. (2012) Job satisfaction in the marine and estuarine fisheries of Guinea-Bissau. Social Indices Research, 109, 11-23.

Fulanda, B., Munga, C., Ohtomi, J., Osore, M., Mugo, R. \& Hossain, M.Y. (2009) The structure and evolution of the coastal migrant fishery of Kenya. Ocean \& Coastal Management, 52, 459-466.

Gacitua-Mario, E., Nordang, H. \& Wodon, Q. (2007) Livelihoods in Guinea-Bissau. In Conflict, Livelihoods, and Poverty in Guinea-Bissau: World Bank Working Paper No. 88 (eds B. Boubacar-Sid, E.G.E. Creppy, E. Gacitua-Mario \& Q. Wodon), pp. 59-76. The World Bank, Washington, DC, USA.

GEF (2012) Financing the Achievement of the Aichi Targets. Global Environment Facility, Washington, DC, USA.

Gell, F.R. \& Roberts, C.M. (2003) Benefits beyond boundaries: the fishery effects of marine reserves. Trends in Ecology \& Evolution, 18, 448-455.
GonZÁlez, J.M. (2010) ll Encuesta sobre los aspectos socioeconómicos de la Pesca Artesanal en Guinea-Bissau Republica da Guine-Bissau Secretaira de Estado das Pescas. FAO, Rome, Italy.

Gutiérrez, N.L., Hilborn, R. \& Defeo, O. (2011) Leadership, social capital and incentives promote successful fisheries. Nature, 470, 386-389.

HaAkonsen, J. M. (1991) The role of migrating fishermen in West Africa: what we know and what we still need to learn. In $L a$ Recherche Face à la Pêche Artisanale (eds J.R. Durand, J. Lemoalle \& J. Weber), pp. 709-715. ORSTOM-IFREMER, Montpellier, France.

Halpern, B.S., Lester, S.E. \& Kellner, J.B. (2009) Spillover from marine reserves and the replenishment of fished stocks. Environmental Conservation, 36, 268-276.

Hilborn, R., Stokes, K., Maguire, J.J., Smith, T., Botsford, L.W., MANGEL, M. et al. (2004) When can marine reserves improve fisheries management? Ocean \& Coastal Management, 47, 197-205.

Hind, E.J., Hiponia, M.C. \& Gray, T.S. (2010) From communitybased to centralised national management-a wrong turning for the governance of the marine protected area in Apo Island, Philippines? Marine Policy, 34, 54-62.

Igoe, J. \& Brockington, D. (2007) Neoliberal conservation: a brief introduction. Conservation \& Society, 5, 432-449.

Jennings, S., Smith, A.D.M., Fulton, E.A. \& Smith, D.C. (2014) The ecosystem approach to fisheries: management at the dynamic interface between biodiversity conservation and sustainable use. Annals of the New York Academy of Sciences, 1322, 48-60.

Jentoft, S. (2005) Fisheries co-management as empowerment. Marine Policy, 29, 1-7.

Jentoft, S. (2014) Walking the talk: implementing the international voluntary guidelines for securing sustainable small-scale fisheries. Maritime Studies, 13,16

Jentoft, S., Chuenpagdee, R. \& Pascual-Fernandez, J.J. (2011) What are MPAs for: on goal formation and displacement. Ocean \& Coastal Management, 54, 75-83.

Jones, P.J.S., Qiu, W. \& De Santo, E.M. (2013) Governing marine protected areas: social-ecological resilience through institutional diversity. Marine Policy, 41, 5-13.

KACZYNSKI, V.M. \& FlUharTy, D.L. (2002) European policies in West Africa: who benefits from fisheries agreements? Marine Policy, 26, 75-93.

KACZYNSKI, V.M. \& LoONEY, S.W. (2000) Coastal resources as an engine of economic growth and reduction of poverty in West Africa: policy considerations. Coastal Management, 28, 235-248.

KAISER, M.J. (2005) Are marine protected areas a red herring or fisheries panacea? Canadian Journal of Fisheries and Aquatic Sciences, 62, 1194-1199.

Kawarazuka, N. \& Béné, C. (2011) The potential role of small fish species in improving micronutrient deficiencies in developing countries: building evidence. Public Health Nutrition, 14, 1927-1938.

Leeney, R.H. \& Poncelet, P. (2015) Using fishers' ecological knowledge to assess the status and cultural importance of sawfish in Guinea-Bissau. Aquatic Conservation: Marine and Freshwater Ecosystems, 25, 411-430.

Leeney, R.H., Weir, C.R., Campredon, P., Regalla, A. \& Foster, J. (2015) Occurrence of Atlantic humpback (Sousa teuszii) and bottlenose (Tursiops truncatus) dolphins in the coastal waters of Guinea-Bissau, with an updated cetacean species checklist. Journal of the Marine Biological Association of the United Kingdom. Http:// dx.doi.org/10.1017/Soo25315415000661

Lester, S.E. \& HALPERN, B.S. (2008) Biological responses in marine no-take reserves versus partially protected areas. Marine Ecology Progress Series, 367, 49-56. 
Levin, S.A. \& Lubchenco, J. (2008) Resilience, robustness, and marine ecosystem-based management. BioScience, 58, 27-32.

MacKinnon, K., Dudley, N. \& Sandwith, T. (2011) Natural solutions: protected areas helping people to cope with climate change. Oryx, 45, 461-462.

Maretti, C.C. (2003) The Bijagós Islands-culture, resistance and conservation. Policy Matters, 12, 121-131.

Mascia, M.B. \& Claus, C.A. (2009) A property rights approach to understanding human displacement from protected areas: the case of marine protected areas. Conservation Biology, 23, 16-23.

Mascia, M.B. \& Pailler, S. (2011) Protected area downgrading, downsizing, and degazettement (PADDD) and its conservation implications. Conservation Letters, 4, 9-20.

Miller, B.W., Caplow, S.C. \& Leslie, P.W. (2012) Feedbacks between conservation and social-ecological systems. Conservation Biology, 26, 218-227.

Mora, C. \& SAle, P.F. (2011) Ongoing global biodiversity loss and the need to move beyond protected areas: a review of the technical and practical shortcomings of protected areas on land and sea. Marine Ecology Progress Series, 434, 251-266.

Mwaipopo, R.N. (2008) The Social Dimensions of Marine Protected Areas: A Case Study of the Mafia Island Marine Park in Tanzania. International Collective in Support of Fishworkers, Chennai, India.

Nielson, M.R. \& Lund, J.F. (2012) Seeing white elephants? The production and communication of information in a locally-based monitoring system in Tanzania. Conservation \& Society, 10, 1-14.

NJAYA, F., Donda, S. \& BÉNÉ, C. (2012) Analysis of power in fisheries co-management: experiences from Malawi. Society \& Natural Resources, 25, 652-666.

NunAN, F. (2014) Wealth and welfare? Can fisheries management succeed in achieving multiple objectives? A case study of Lake Victoria, East Africa. Fish and Fisheries, 15, 134-150.

Nursey-Bray, M. \& Rist, P. (2009) Co-management and protected area management: achieving effective management of a contested site, lessons from the Great Barrier Reef World Heritage Area (GBRWHA). Marine Policy, 33, 118-127.

Peluso, N.L. (1993) Coercing conservation? The politics of state resource control. Global Environmental Change, 3, 199-217.

RANDALL, S. (2005) Review of literature on fishing migrations in West Africa-From a demographic perspective. Sustainable Fisheries Livelihoods Programme. Http://www.transparentsea.co/images/2/ 29/Randall_(2005).pdf [accessed 4 January 2015].

Ratner, B.D., Asgard, B. \& Allison, E.H. (2014) Fishing for justice: human rights, development, and fisheries sector reform. Global Environmental Change, 27, 120-130.

Ritchie, J., Lewis, J., Nicholls, C.M. \& Ormston, R. (2014) Qualitative Research Practice: A Guide for Social Science Students and Researchers. Second edition. SAGE Publications Ltd, London, UK.

Rodwell, L.D. \& Roberts, C.M. (2004) Fishing and the impact of marine reserves in a variable environment. Canadian Journal of Fisheries and Aquatic Sciences, 61, 2053-2068.
Russell, A.J.M. \& Dobson, T. (2011) Chiefs as critical partners for decentralized governance of fisheries: an analysis of co-management case studies in Malawi. Society \& Natural Resources, 24, 734-750.

Schmidt-Soltau, K. \& Brockington, D. (2007) Protected areas and resettlement: what scope for voluntary relocation? World Development, 35, 2182-2202.

Slater, M.J., Mgaya, Y.D. \& Stead, S.M. (2014) Perceptions of rulebreaking related to marine ecosystem health. PLoS ONE, 9(2), e89156.

Song, A.M., Chuenpagdee, R. \& Jentoft, S. (2013) Values, images, and principles: what they represent and how they may improve fisheries governance. Marine Policy, 40, 167-175.

Stevens, K., Irwin, B., Kramer, D. \& Urquhart, G. (2014) Impact of increasing market access on a tropical small-scale fishery. Marine Policy, 50, 46-52.

Sumaila, U.R., Khan, A.S., Dyck, A.J., Watson, R., Munro, G., Tydemers, P. \& Pauly, D. (2010) A bottom-up re-estimation of global fisheries subsidies. Journal of Bioeconomics, 12, 201-225.

TEH, L.C.L. \& Sumaila, U.R. (2013) Contribution of marine fisheries to worldwide employment. Fish and Fisheries, 14, 77-88.

Tous, P., Ducroce, M., Bucal, D. \& Feron, E. (1998) Shark populations are possibly under serious threat in the Bijagós archipelago (Biosphere Reserve), Guinea-Bissau, West Africa. Shark News, 10, 4.

Tvedten, I. (1990) The difficult transition from subsistence to commercial fishing: the case of the Bijagós of Guinea-Bissau. MAST, 3, 119-130.

Urquhart, J., Acott, T. \& Zhao, M. (2013) Introduction: social and cultural impacts of marine fisheries. Marine Policy, 37, 1-2.

Warner, T.E. \& Pomeroy, R.S. (2012) Paths of influence: the direct and indirect determinants of marine managed area success. Coastal Management, 40, 250-267.

Weeratunge, N., Béné, C., Siriwardane, R., Charles, A., Johnson, D., Allison, E.H. et al. (2014) Small-scale fisheries through the wellbeing lens. Fish and Fisheries, 15, 255-279.

Woodley, S., Bertzky, B., Crawhall, N., Dudley, N., Londoño, J.M., MacKinnon, K. et al. (2012) Meeting Aichi target 11: what does success look like for protected area systems? Parks, 18, 23-36.

Zappes, C.A., Da Silva, C.V., Pontalti, M., Danielski, M.L. \& Di Beneditto, A.P.M. (2013) The conflict between the southern right whale and coastal fisheries on the southern coast of Brazil. Marine Policy, 38, 428-437.

\section{Biographical sketch}

Helen Cross's interests developed from sea-turtle nesting ecology to wider turtle population dynamics, before focusing on human-ecological interactions. She has contributed to sea-turtle conservation efforts in Costa Rica and Panama (Endangered Wildlife Trust UK), Greece (Sea Turtle Protection Society) and Lebanon (Mediterranean Association to Save the Sea Turtles). Helen now works with the Bioclimate research and development group, based in Edinburgh, UK. 